

ISSN $1814-5868$
Available online at http://bajas.edu.iq https://doi.org/10.37077/25200860.2019.260 College of Agriculture, University of Basrah
Basrah Journal of Agricultural Sciences

\title{
Polymorphism of Myostatin Gene and its Association with Body Weight of Iraqi Local Ducks
}

\author{
Ali. J. Ghali* \& Sajida A. Al-shaheen
}

Department of Animal Production, College of Agriculture, University of Basrah, Iraq *Corresponding author e-mail: ali9j3gh@gmail.com

Received 19 September 2019; Accepted 18 November 2019; Available online 22 November 2019

\begin{abstract}
Myostatin, or growth and differentiation factor-8(GDF-8) is a member of the transforming growth factor (TGF)- $\beta$ superfamily. The objective of this study was to investigate the association between genetic polymorphism of the myostatin gene with the body-weight of Iraqi local ducks by DNA sequence analysis. The results of DNA sequence showed nitrogen base change $(G>A)$ at 129 base pair sites of the exon1 of MSTN gene. Therefore, two alleles, G and A and two patterns of genotypes, GG, AG were observed. The observed numbers of GG and AG genotypes were 25 and 6 , respectively. The $\mathrm{G}$ allele was of the highest frequency (0.9) while A allele showed the lowest frequency (0.1). The GG genotype showed the highest frequency $(80.65 \%)$ and AG genotype showed the lowest frequency (19.35\%). Additionally, the percentages of observed and expected heterozygosity were 0.19 and 0.17 respectively. Moreover, the percentages of observed and expected homozygosity were 0.80 and 0.82 , respectively. The average heterozygosity was 0.17 . The results revealed no significant $(\mathrm{P}>0.05)$ effect of the MSTN gene on body weight.
\end{abstract}

Keywords: Myostatin gene, Iraqi local ducks, polymorphism, DNA sequence analysis.

\section{Introduction}

The great latest advances during the few decades at molecular genetics level and DNA technology created significant changes in the animal breeding and genetic improvement field. Determination of influential genes of many economic traits may open interesting prospects for future selection programs, especially marker-assisted selection (Sabir et al., 2014 ; Nandedkar et al., 2016). Myostatin gene also called a specialized growth factor 8 (GDF 8) that belongs to a wide range of growth proteins that are called (TGF- $\beta$ ) family. It involves the negative regulator of skeletal muscle development and body mass (Saxena et al., 2009). In poultry, myostatin controls muscle cells' growth before and after hatching and repair damaged muscle fibres, in

addition to its role in the regulation of the final number and growth of muscle fibers (Langley et al., 2002; Zhang et al., 2019). Numerous studies have shown that myostatin protein is produced mainly in skeletal muscles, and it consists of 376 amino acids in domestic birds such as chickens and ducks (Lee \& McPherron 2001; Tries et al., 2001; Wolfman et al., 2003). Loss of MSTN function because of mutations associated with increased skeletal muscle mass and pleiotropic effects have been observed in chickens (Mcfarland et al., 2007). A number of studies by different researchers (Zhang et 
al., 2011; Paswan et al., 2014) reported that genetic polymorphisms of the MSTN gene have many effects on productive traits such as body weight, weight gain, carcasses specifications and reproductive efficiency. Respecting studies on ducks (Lu et al., 2011 ; Gong et al., 2014) found different effects of MSTN gene mutations on body weights at different ages, explaining that the nitrogen base change due to genetic mutation may alter an amino acid that has an effect on body weight during the growth phase. Thus, the MSTN gene could be considered as primarily responsible for muscle development and could be a potential candidate gene for muscle growth-genetic analysis. Due to the adaptability of the local duck in Iraq to the environmental conditions and the lack of focus on it as a source of diversity and meat production in programs of genetic improvement, this study aimed to detect the association between polymorphism of MSTN gene with body weight.

\section{Material \& Methods}

\section{Experimental birds}

This study carried out at the duck hall, animal production farm, College of Agriculture, The University of Basrah for the period from $22 \backslash 11 \backslash 2018$ up to $30 \backslash 4 \backslash 2019$. The study included 80 chicks of local ducks. Chicks were housed up to 10 weeks of age in pens of ( $3.5 \mathrm{~m}^{2}$ space) on deep litter. Birds were fed ad libitum commercial diets according to their age: a starter diet (from 0 to 3 week of age) containing $20 \%$ crude protein and $2900 \mathrm{kcal}$ of metabolizable energy and a grower diet (from 4 to 10 week of age) containing $18 \%$ crude protein and $3100 \mathrm{kcal}$ of metabolizable energy according to the recommendation of NRC (1994). Birds had also free access to water. The lighting program during the experimental period was by the use of (5001000) watts lamps. The temperature degree inside pens was $\left(32-34^{\circ} \mathrm{C}\right)$ during the first week of age and then it was decreased gradually to $30^{\circ} \mathrm{C}$ with preceding age. The experimental birds were individually weighed at $4,6,8$ and 10 weeks of age by using a sensitive balance.

\section{Isolation of genomic DNA}

This part of the work was conducted at genetic engineering laboratory $\backslash$ College of Agriculture, The University of Basrah. Genetic analysis was conducted to extract genetic material and determine the genotypes of MSTN gene and find out its relationship with body weight. From all birds (aged 10 weeks), blood samples were collected into test tubes containing EDTA. Genomic DNA was isolated from aliquots of $100 \mu \mathrm{l}$ of blood samples using a genomic DNA extraction kit, Geneaid according to the manufacturer's instructions. The quality and quantity of the DNA template were measured using a Nanodrop spectrophotometer (Thermo Scientific, Fisher Scientific, Loughborough, UK). Genomic DNA samples were stored at $18 \mathrm{c}$ until subjected to DNA sequencing analysis.

\section{Amplification of MSTN Gene:}

This part of the work has accomplished after sending DNA samples to Yang Ling Tianrum Acka Biotechnology Chinese Company. The MSTN gene was amplified with the following primers: forward 5TGCAAAAGCTAGCAGTCTATGT-3, reverse 5-AAGAGCCATCGCTACTGTCG3. This primer was designed from the duck MSTN gene (Gene bank accession NO EU 33699). The polymerase chain reaction was performed in $30 \mu \mathrm{L}$ total volume using $4 \mu \mathrm{L}$ of genomic DNA, $15 \mu \mathrm{L}$ of Master mix, $1 \mu \mathrm{L}$ for each of forward and reverse primers and 8 $\mu \mathrm{L}$ of distilled water. The time and temperature of the thermal polymerase device 
Ghali \& Al-shaheen / Basrah J. Agric. Sci., 32(Spec. Issue 2):97-104, 2019

have been set depending on the optimum temperature of myostatin primers (table 1).

Table (1): Program of myostatin gene used in PCR reaction.

\begin{tabular}{cccc}
\hline Stages & Temperature ${ }^{\circ} \mathrm{C}$ & Time & Cycles \\
\hline Pre-denaturation & 95 & $3 \mathrm{~min}$ & 1 \\
\hline Denaturation & 95 & $45 \mathrm{sec}$ & \multirow{2}{*}{30} \\
\hline Elongation & 55 & $30 \mathrm{sec}$ & \\
\hline Elongation & 72 & $45 \mathrm{sec}$ & 1 \\
\hline Final- Elongation & 72 & $5 \mathrm{~min}$ & \\
\hline
\end{tabular}

\section{DNA Sequence Analysis}

After identifying and revealing PCR products using electrophoreses and products purification. Sequencing was performed to analyze the nucleotides sequences of the target region of exon 1 of the MSTN gene and to identify the mutation site. Assembly of the forward and reverse strands were done using codon code aligner 7.1.1 (codon code corporation). The alignment of sequences also was done using the Bio Edit program (Hall, 1999). Popgene (the reference) program was used to estimate population parameters, T-test was used to compre the statistical differences between the body weights of the two genotypes (SPSS, 2016).

\section{Results \& Discussion}

\section{Polymorphism of MSTN Gene}

A total of (32) samples were successfully amplified (figure1) and sequenced according to MSTN gene partial exon1 (figure2). One nitrogen base change was identified. This nitrogen base change was $(\mathrm{G}>\mathrm{A})$ at 129 base pair sites of the exon1 of the MSTN gene (Gene Bank accession number LC495884. 1129A. G), where the Guanine (G) nitrogen base has replaced by Adenine (A) nitrogen base (Figure2). Consequently, the $\mathrm{G}$ and $\mathrm{A}$ alleles were indicated and derived two different patterns of genotypes, GG and AG.

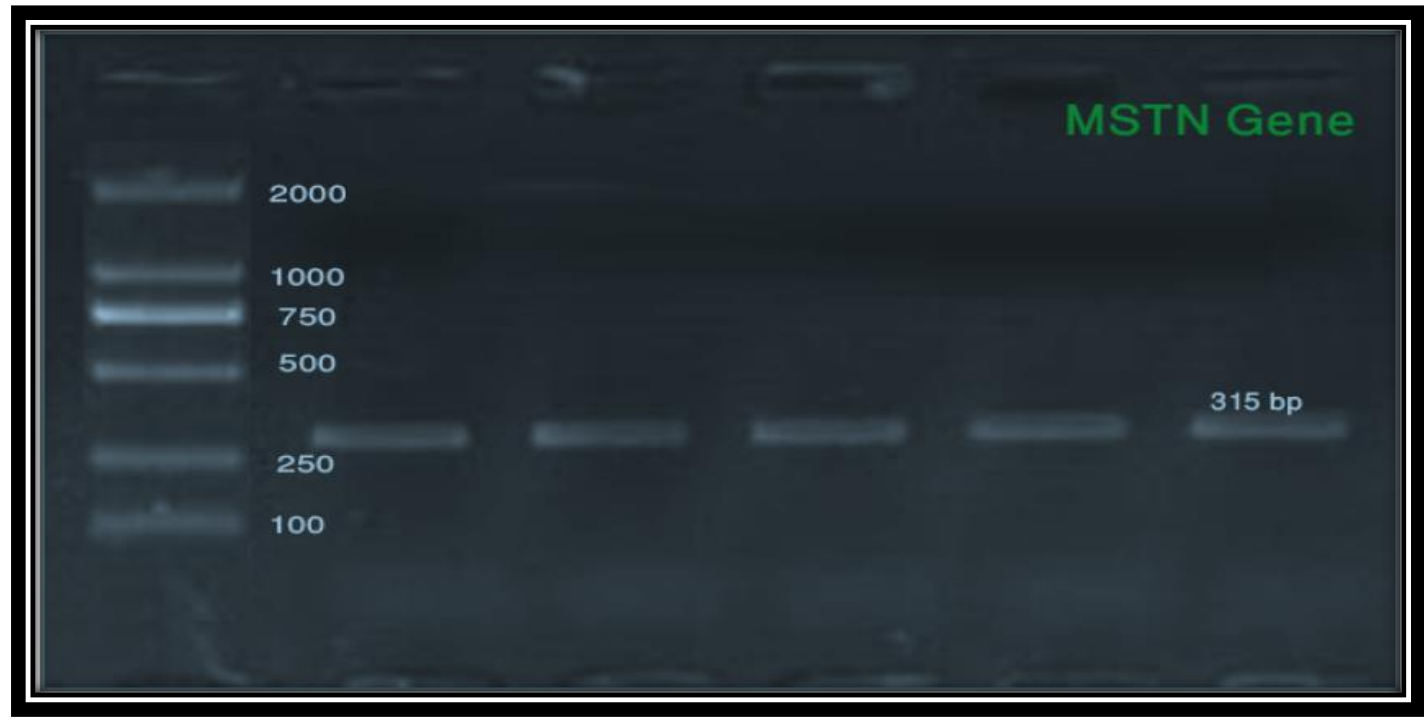

Fig (1): Amplification product of myostatin gene on agarose gel. 


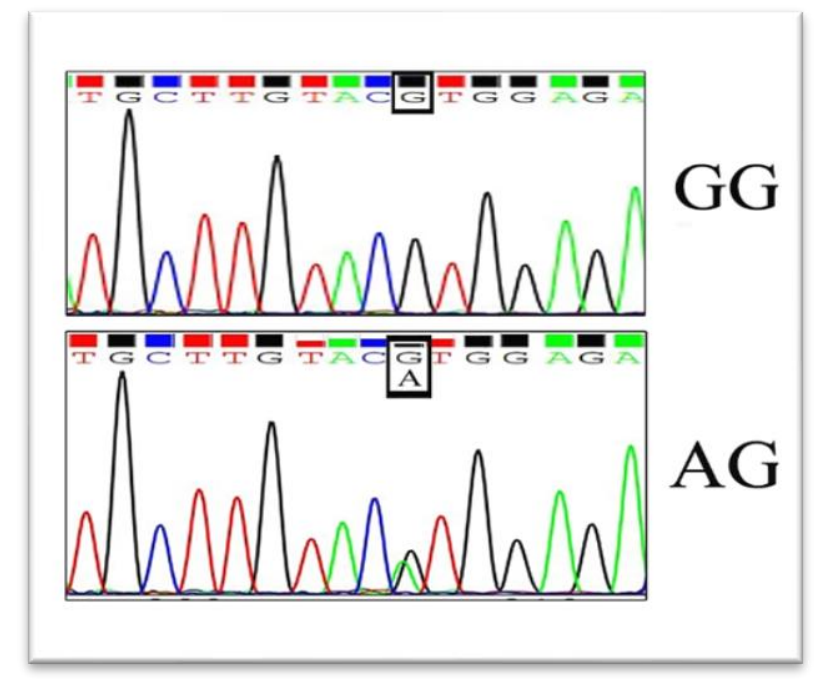

Fig. (2): Site of nitrogen base change of the myostatin gene.

Alleles and genotype frequencies are described in table (2). The observed numbers of $\mathrm{GG}$ and $\mathrm{AG}$ genotypes were 25 and 6,respectively.The numbers of $\mathrm{G}$ alleles were 50 respecting GG genotype, and the numbers of $\mathrm{G}$ and $\mathrm{A}$ alleles were six respecting $\mathrm{AG}$ genotype. The results also revealed that the GG genotype showed the highest frequency (80.65) whereas AG genotype revealed the lowest frequency (19.35). Our results also showed that the total expected numbers of GG and AG genotypes were 25.24 and 5.50, respectively. The current results indicate that the lack of genetic improvement programs for local ducks in Iraq and a small sample size of birds used in this study may be the causes of differences in genotypes frequencies.

Table (2): Observed numbers of genotypes, allele's numbers, genotype frequencies, expected numbers and chi-square $\left(\mathrm{X}^{2}\right)$.

\begin{tabular}{|c|c|c|c|c|c|}
\hline The Gene & Genotypes & Observed numbers & $\begin{array}{c}\text { genotype } \\
\text { frequencies }\end{array}$ & $\begin{array}{l}\text { expected } \\
\text { numbers }\end{array}$ & $X^{2}$ \\
\hline \multirow{2}{*}{ MSTN } & GG & 25 & 80.65 & 25.24 & \\
\hline & $\mathrm{AG}$ & 6 & 19.35 & 5.5 & 0.29 \\
\hline \multicolumn{2}{|c|}{ Total } & 31 & 100 & 30.74 & \\
\hline
\end{tabular}

The results of allelic frequencies shown in the table (3) represented that the $\mathrm{G}$ allele had the highest frequency (0.9) while A allele showed the lowest frequency (0.1). Lu et al. (2011) found three genotypes (AA, AB and
BB) of the MSTN gene at G753A, G658T, and $\mathrm{G} 235 \mathrm{C}$ sites of mutations in different lines of ducks. Xu et al. (2013) also found three genotypes (AA, AB and $\mathrm{BB}$ ) of MSTN gene at $\mathrm{T} 129 \mathrm{C}, \mathrm{T} 780 \mathrm{C}$ and $\mathrm{T} 952 \mathrm{C}$ sites of 
mutations in pekin ducks. The two previous stated studies showed different observed numbers of genotypes according to the mutation site and the sample size of birds used in those studies. Our results indicate a higher frequency of $\mathrm{G}$ allele compared to $\mathrm{A}$ allele, which may be due to the higher adaptability to the environmental conditions for individuals carrying $G$ allele within their genotypes in comparison with individuals carrying $\mathrm{A}$ allele. In this regard, $\mathrm{Xu}$ et al. (2013) found that gene frequencies of $A$ and $\mathrm{B}$ alleles were 0.53 and 0.47 , respectively at three mutated sites (T126 C, T $708 \mathrm{C}$ and T $952 \mathrm{C}$ ) of MSTN gene in ducks. In addition, in a study of the MSTN polymorphisms in (White Liancheng ${ }^{x}$ Whit Kaiya) duck cross
(Gong et al., 2014) the results showed frequencies (0.31 and 0.69) for $G$ and $A$ alleles, respectively at G 129 A SNP site of exon1 of MSTN gene, while frequencies of T and $\mathrm{C}$ alleles were 0.39 and 0.61 , respectively at C324T SNP site of exon2 of MSTN gene. In chickens, Paswan et al. (2014) found that frequency of A allele was higher (0.76) than that of B allele (0.24). Respecting $\chi^{2}$ analysis, the value of $\chi^{2}$ was 0.29 which revealed that the ducks' population in our study is in equilibrium with the Hardy-Weinberg equation. Zhao et al. (2016) found equilibrium status with the Hardy-Weinberg in a population of Pekin ducks in the study of polymorphisms in exon1 and exon3 of the MSTN gene.

Table (3): Allele frequencies of the MSTN gene and Fixation Index.

\begin{tabular}{ccc}
\hline Allele & Allele frequencies & Fixation Index \\
\hline $\mathrm{A}$ & 0.1 & \\
\hline $\mathrm{G}$ & 0.9 & -0.314 \\
\hline Total & 1 & \\
\hline
\end{tabular}

\section{Heterozygosity and Homozygosity Percentages}

Table (4) showed that the percentages of observed and expected heterozygosity were 0.19 and 0.17 , respectively. The percentages of observed and expected homozygosity were 0.80 and 0.82 , respectively. The average heterozygosity was 0.17 . From our current results, it can be observed that the small size of ducks' sample in this study may have an effect on the different distribution of the percentages of heterozygosity, homozygosity and the average heterozygosity. Moreover, due to the unplanned breeding of local ducks in Iraq and the lack of genetic improvement programs, this may have an impact on the different percentages of observed and expected heterozygosity and homozygosity. Our results are similar to those of Zhao et al. (2016) in a study of the MSTN gene polymorphism in Sansui ducks, where the observed and expected percentages of heterozygosity were convergent at $106 \mathrm{G}>\mathrm{A}$ SNP $(0.50,0.49)$, respectively and also at 159 $\mathrm{G}>\mathrm{A}(0.50,0.49)$, respectively of the exon1. The percentages of observed and expected heterozygosity were also close together at $5368 \mathrm{G}>\mathrm{A}$ SNP $(0.55,0.44)$ and at $5389 \mathrm{~A}>\mathrm{C}$ $(0.55,0.44)$, respectively of the exon 3 . 
Ghali \& Al-shaheen / Basrah J. Agric. Sci., 32(Spec. Issue 2):97-104, 2019

Table (4): Observed and Expected percentages of Heterozygosity and Homozygosity and the average of Heterozygosity.

\begin{tabular}{cccccc}
\hline Sample size & $\begin{array}{c}\text { Observed } \\
\text { Hetero } \\
\text { zygosity } \\
(\%)\end{array}$ & $\begin{array}{c}\text { Expected } \\
\text { Hetero } \\
\text { zygosity } \\
(\%)\end{array}$ & $\begin{array}{c}\text { Observed } \\
\text { Homo } \\
\text { zygosity } \\
(\%)\end{array}$ & $\begin{array}{c}\text { Expected } \\
\text { Homo } \\
\text { zygosity } \\
(\%)\end{array}$ & $\begin{array}{c}\text { average of } \\
\text { Hetero } \\
\text { zygosity }\end{array}$ \\
\hline 62 & 0.19 & 0.17 & 0.80 & 0.82 & 0.17 \\
\hline
\end{tabular}

\section{Effect of MSTN Gene on body weight}

Table (5) revealed no significant $(p \leq 0.05)$ effect of the MSTN gene on body weights at 4, 6,8 and 10 weeks of age. Although the differences of body weights of $\mathrm{AG}$ and $\mathrm{GG}$ genotypes did not reach the level of significance, birds of AG genotype were mathematically higher in body weights than other genotypes. This result may be due to the positive effect of $G$ allele on body weight in birds of AG genotype as in birds of GG genotypes. Our current finding did not agree with those of Lu et al. (2011) that indicated superiority of AG genotype compared to AA genotype in body weight at 6 weeks of age (2652.64 and $2611.12 \mathrm{~g}$, respectively) at G753A site of the MSTN polymorphism. As well as, GT genotype exceeded GG genotype in body weight at 6 weeks of age (2807and $2736 \mathrm{~g}$, respectively) at G658T site of the MSTN polymorphism. On the other hand, Gong et al. (2014) found significant proceeding for GA genotype in comparison with GG genotype in body weights at 4, 6, 8 and 10 weeks of age that were $(1373.99,1810.65,1895$ and 1892) g, respectively for GA genotype and (921,1406.47, 1881.57 and 1972.16) g, respectively for GG genotype. The previous study showed that the change of the nitrogen base as a result of mutation will cause change in particular amino acids that may affect body weights during growth stage. This inconsistency in the results may be ascribed to breed differences used in the studies, populations and sampling size and frequency distribution of genetic variants.

Table (5): Effect of the MSTN genotype on body weight of local duck (Mean \pm Standard deviation).

\begin{tabular}{|c|c|c|c|c|c|c|}
\hline \multirow{2}{*}{ Genotype } & \multirow{2}{*}{ Numbers } & \multicolumn{4}{|c|}{ Age $\backslash$ Weeks } & \multirow{2}{*}{$\begin{array}{l}\text { Body } \\
\text { Weigh } \\
\text { mean }\end{array}$} \\
\hline & & 4 & 6 & 8 & 10 & \\
\hline $\mathrm{AG}$ & 4 & $740.0 \pm 21.2$ & $\begin{array}{c}1250.0 \\
\pm 0.0^{*}\end{array}$ & $\begin{array}{c}1790.0 \\
\pm 0.0^{*}\end{array}$ & --- & $1260.0^{\mathrm{a}}$ \\
\hline GG & 12 & $722.5 \pm 7.67$ & $\begin{array}{l}1220.0 \\
\pm 13.22\end{array}$ & $\begin{array}{l}1773.3 \\
\pm 12.58\end{array}$ & $\begin{array}{r}2025.0 \\
\pm 73.59\end{array}$ & $1238.6^{\mathrm{a}}$ \\
\hline \multicolumn{2}{|c|}{ Age mean } & $731.25^{d}$ & $1235.0^{c}$ & $1781.65^{b}$ & $2025.0^{\mathrm{a}}$ & \\
\hline Different & letters & show & significant & differ & $(\mathrm{p}$ & $\leq 0.05)$ \\
\hline
\end{tabular}




\section{Conclusions}

We concluded from our study the possibility of using the MSTN gene polymorphism as a molecular marker in selection programs for growth-related traits with an increasing sample size of local Iraqi ducks.

\section{Acknowledgments}

We thank the University of Basrah, and all who helped me or supported me in completing my work in this study.

\section{References}

Gong, P.; Yang, Y.;Yang, Y.; Ye, S.; Deng, B.; Wang, L.; Yu, T.; Qian, Y. \& Gong, Y. (2014). Effects of polymorphisms and haplotypes within the MSTN gene on duck growth trait. Brit. Poult. Sci., 55(1): 37-43.

Hall, T.A. (1999). BioEdit: A user-friendly biological sequence alignment editor and analysis program for Windows 95/98/NT. In Nucleic acids Symp. Ser., 41: 95-98:

Langley, B.; Thomas, M.; Bishop, A.; Sharma, M.;Gilmour, S.; Kambadur, R. (2002). Myostatin inhibits myoblast differentiation by down-regulating MyoDexpression. J. Biol. Chem., 277: 49831-49840.

Lee, S.J. \& McPherron, A.C. (2001). Regulation of myostatin activity and muscle growth. P. Natl. Acad. Sci., 98(16): 9306-9311.

Lu, J.; Hou, S.; Huang, W.; Yu, J. \& Wang, W. (2011). Polymorphisms in the myostatin gene and their association with growth and carcass traits in duck. Afr. J. Biotechnol., 10(54): 11309-11312 .

Mcfarland, D.C.; Velleman, S.G.; Pessall, J.E \& Liu, C. (2007). The role of myostatin in chicken (Gallus domesticus) myogenic satellite cell proliferation and differentation. Genet. Endocrinol., 151(3): 351-357.

Nandedkar, P.; Saxena, V.; Saxena, M., Ahmed, K.; Kumar, S., Singh, R.; Jain, P.; Jawale, M. \& Nehete, S. (2016). PCRRFLP-gene study in musculoskeletal deformed birds. Indiaz Res. J. Exten. Educ., 14(4): 78-81.

NRC (National Research Council). (1994). Nutrient Requirements of Poultry. $9^{\text {th }}$ Rev. ed. National Academy Press. Washington, D.C.: $176 p p$.

Paswan, C.; Bhattacharya, T.; Nagaraj, C.; Chaterjee, R. \& Jayashankar, M. (2014). SNPs in minimal promoter of myostatin (GDF-8) gene and its association with body weight in broiler chicken. J. Appl. Anim. Res., 42(3): 304-309.

Sabir, J.; Mutwakel, M.; El-Hanafy, A.; AlHejin, A.; Abdel Sadek, M.; Abou-Alsoud, M.; Qureshi, M.; Saini, K. \& Ahmed, M. (2014). Applying molecular tools for improving livestock performance: from DNA markers to next generation sequencing technologies. J. Food Agr. Environ., 12(2): 541-553.

Saxena, V.; Sachdev, A.; Gopal, R. \& Pramod, A. (2009). Roles of important candidate genes on broiler meat quality. World's Poult. Sci. J., 65(1): 37-50.

SPSS (2016). Statistical Package for Social Science, User's Guide for statistics Version 24, copyright IBM, SPSS Inc.,USA.

Tries, R.S.; Chen, T.; DaVies, M.V.; Tomkinson, K.N.; Pearson, A.A.; Shakey, Q.A. \& Wolfman, N.M. (2001). GDF-8 propeptide binds to GDF-8 and antagonizes biological activity by inhibiting GDF-8 receptor binding. Growth Factors, 18(4): 251-259.

Wolfman, N. M.; McPherron, A.C.; Pappano, W.N.; Davies, M.V; Song, K.; Tomkinson, K.N.; Wright, J.F.; Zhao, L.; Sebald, S.M. 
Ghali \& Al-shaheen / Basrah J. Agric. Sci., 32(Spec. Issue 2):97-104, 2019

\& Greenspan, D.S. (2003). Activation of latent myostatin by the BMP-1/tolloid family of metalloproteinases. P. Natl. Acad. Sci., 100(26): 15842-15846.

Xu, T.; Gu, L.; Zhang, X.; Ye, B.; Liu, X. \& Hou, S. (2013). Characterization of myostatin gene (MSTN) of Pekin duck and the association of its polymorphism with breast muscle traits. Genet. Mol. Res., 12(3): 3166-3177.

Zhang, G.; Ding, F.; Wang, J.; Dai, G.; Xie, K.; Zhang, L.; Wang, W. \& Zhou, S. (2011). Polymorphism in exons of the myostatin gene and its relationship with body weight traits in the Bian chicken. Biochem. Genet., 49(1-2): 9-19.

Zhang, Y.; Wang, Y.; Yulin, B.; Tang, B.; Wang, M.; Zhang, C.; Zhang, W.; Jin, J.; Li, T. \& Zhao, R. (2019). CRISPR/Cas9mediated sheep MSTN gene knockout and promote sSMSCs differentiation. J. Cell Biochem., 120(2): 1794-1806.

Zhao, Z. H.; Li, H.; Yi, H. J. \& Peng, B. X. (2016). The correlation between polymorphisms of the MSTN Gene and slaughter traits in Sansui Ducks. Pak. J. Zool., 48(5): 1283-1290. 